\title{
Editorial
}

\section{The European Section and Board of Gastroenterology and Hepatology: What's New?}

\section{Isabelle Cremers}

Serviço de Gastrenterologia, Hospital de S. Bernardo, Setúbal, Portugal

\section{A Secção e Board Europeus de Gastrenterologia e Hepatologia: Situação Actual}

The European Section and Board of Gastroenterology and Hepatology (ESBGH) is one of the Specialist Sections of UEMS (The European Union of Medical Specialists), which was founded in 1958 and represents >1.6 million Medical Specialists, working in 37 countries.

Two delegates from each UEMS member country are selected as National Delegates to provide a balance between professional defenders and academics. The Section and Board meet twice a year.

The routine business of the Section and Board of Gastroenterology and Hepatology is carried out by an Executive Committee.

\section{Functions of the ESBGH}

- Define, assess, and secure the standards of education and training in Gastroenterology and Hepatology.

- Evaluate the quality of International Gastroenterology and Hepatology CME/CPD in conjunction with EACCME.

\begin{tabular}{|c|c|}
\hline KARGER & (C) 2017 Sociedade Portuguesa de Gastrenterologia \\
\hline 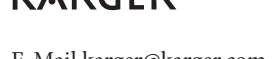 & $\begin{array}{l}\text { Karger } \\
\text { Open access }\end{array}$ \\
\hline www.karger.com/pjg & $\begin{array}{l}\text { This article is licensed under the Creative Commons Attribution- } \\
\text { NonCommercial-NoDerivatives } 4.0 \text { International License (CC BY- } \\
\text { NC-ND) (http://www.karger.com/Services/OpenAccessLicense). } \\
\text { Usage and distribution for commercial purposes as well as any dis- } \\
\text { tribution of modified material requires written permission. }\end{array}$ \\
\hline
\end{tabular}

- Promote exchange of trainee gastroenterologists and hepatologists.

- Collect and analyse workforce demographics in Gastroenterology and Hepatology.

\section{Curriculum - The Blue Book 2017}

The newly revised curriculum, with UEG, EASL, and the EJD represented on the writing group, is available at http://www.eubogh.org/blue-book.

The following is described in the Blue Book: the roles of the UEMS relationship with the ESBGH, the definition of the speciality, the vision, purpose, and key objectives of the ESBGH, explanations about the Fellowship of the ESBGH and about Training Centre Accreditation, and a description of the ESBGH Examination.

The setting and organization of the Training Programme, including training requirements for trainees, trainers, and training institutions are described.

The Core Curriculum has been thoroughly reviewed and is divided in several parts:

- Basic competences in gastroenterology and hepatology

- Policies on safeguarding children and vulnerable adults

Dr. M. Isabelle Cremers

Serviço de Gastrenterologia, Hospital de S. Bernardo

R. Camilo Castelo Branco

PT-2910-446 Setúbal (Portugal)

E-Mail cremers.tavares@gmail.com 
- Competencies and training related to common presentations

- Competencies and training related to diseases and their management

- Endoscopy training

- Ultrasound training curriculum interventional ultrasound (INVUS 1)

In light of the increasing specialization and demands of the speciality, the Higher Training Modules were also reviewed, including:

- Digestive oncology

- Advanced hepatology curriculum

- Higher training in nutrition

- Interventional endoscopy curriculum

- EUS interventions (INVUS 2)

\section{ESBGH Subcommittees}

- Continuing Medical Education (CME Committee): Chair, Ludwig Kramer: ludwig.kramer@wienkav.at

The CME Committee assesses the educational content of gastroenterology meetings throughout Europe and further afield for the award of CME credits in conjunction with EACCME. The CME Committee evaluates around 50-75 Live Learning events and 5-10 E-Learning applications each year. It takes part in UEMS/EACCME consultations and meetings and is actively implementing the EACCME 2.0 guidelines on assessing CME applications (https://www.uems.eu/uems-activities/accreditation/ eaccme).

- Training Recognition Committee (TRC Committee): Chair, Nurdan Tozun:

nurdan.tozun@acibadem.edu.tr

The TRC assesses applicants for the award of the Diploma/Fellowship of the European Section and Board of Gastroenterology and Hepatology. The TRC also inspects Gastroenterology Training Centres throughout Europe and recognizes Centres of sufficient standard as a recognised "Training Centre of the European Board of Gastroenterology and Hepatology".

To date, the ESBGH has awarded 1,477 Fellowships and approved 73 Training Centres, including 6 in Portugal. A seventh Portuguese Centre submitted its application and waits inspection.

- Manpower and Public Affairs Committee (M\&PA Committee): Chair, Gian Dorta: gian.dorta@chuv.ch

The Manpower and Public Affairs Committee of the ESBGH is responsible for collating and acting on Workforce issues across Europe. Surveys are regularly conduct- ed via National ESBGH delegates providing detailed information which is used in planning services and ensuring adequate numbers of trainees.

- Examinations Committee (EC Committee): Chair, Dr. Hannu Nuutinen: hannu.nuutinen@hus.fi

The Examinations Committee is responsible for maintaining the Academic standards of the ESBGH examination by taking part in Question Writing and Standard Setting.

The ESBGH Exam is a fully validated assessment of knowledge of gastroenterology and hepatology as laid down in the Blue Book. The examination has been running since April 2014. For further details, see http://www. eubogh.org/exam.

\section{Eligibility Requirements}

There are no restrictions to entry for the ESBGH exam. There is no limit to the number of attempts that can be made. For doctors in formal Gastroenterology and Hepatology training programmes success is more likely if the exam is taken after the first year.

\section{Remit of the ESBGH Exam}

Success in this exam is a demonstration of having achieved the knowledge necessary to fulfil the requirements of the ESBGH curriculum which is a Europe-wide description of the level expected of a specialist Gastroenterologist and Hepatologist.

The first exam was held on April 23, 2014. Fifty candidates sat in test centres. A post-exam survey had positive evaluations on the content of the exam and about the administration of the exam, the quality of the test centres, etc. The number of candidates doubled in 2015 and 2016. The European ESBGH Exam is now mandatory in Switzerland and the Netherlands. The Examination will be translated into Polish in 2017.

The Examination will make it easier for the gastroenterologist who pass it to find work either in their own countries or when crossing the borders, as we see increasingly. It will help employers to certify that the candidates for the jobs have a high standard of knowledge to treat their patients. Overall, we have had a lot of interest from junior gastroenterologist and trainees as is also evident from the increasing number of candidates.

\section{ESBGH-UEG Activities}

Common Interest Group at the UEGW - 2014-2015. Hot spot - 'The Future of GI Education' - UEGW Vienna, 2016.
106

GE Port J Gastroenterol 2017;24:105-107 DOI: $10.1159 / 000460831$
Cremers 
Educational session - 'Moving GI Education into the future: current challenges, future needs' - UEGW Barcelona, 2017.

Collaboration on targeted provision of Training and Education.

ESBGH booth at UEG meetings.

\section{ESBGH Executive Committee}

President of the Section: Dr. Jean Paul Jacques: jacques.gastro@gmail.com

President of the Board: Dr. Ian Barrison: i.g.barrison@herts.ac.uk
Secretary General, Section and Board: Dr. Isabelle Cremers: cremers.tavares@gmail.com

Treasurer, Section and Board: Dr. Jan Lillienau: jan.lillienau@skane.se

Secretariat Contact: Ana Tavares: executivesecretary@eubog.org

Website: www.eubogh.org

The ESBGH maintains contact with stakeholders through our website, available at www.eubogh.org.

The website contains comprehensive information about the Blue Book, the ESBGH Fellowship, and accreditation of Training Centres. 